\title{
Pragmatics Equivalence of Declarative Utterances Found in Aladdin Movie Script (2019)
}

\author{
Vira Cahya Mukti* \\ Sekolah Pascasarjana, \\ Universitas Muhammadiyah Surakarta \\ Surakarta, Indonesia \\ viracahyamukti@gmail.com
}

\author{
Dwi Haryanti \\ Sekolah Pascasarjana, \\ Universitas Muhammadiyah Surakarta \\ Surakarta, Indonesia \\ dwiharjanti@ums.ac.id
}

\author{
Farrah Zakiyah Anwar \\ Sekolah Pascasarjana \\ Universitas Muhammadiyah Surakarta \\ Surakarta, Indonesia \\ farrahzakiyahanwar@gmail.com
}

\begin{abstract}
This research concerns with declarative speech acts and their translation in Aladdin movie script (2019). The aims of this research are to describe the types of declarative utterances and their translation found in the movie script of Aladdin and to describe the pragmatics equivalence of declarative utterances found in the movie script. The data of this descriptive qualitative research are declarative speech acts and their translation in the movie script in 2 languages. The data collection method are comparison between English and Indonesian script. The data are analyzed using speech act theory of Searle (1969), and pragmatics equivalence by Barker's (1992) theory. The result of the study shows that there are eleven varieties of declarative speech acts, including convincing, surrendering, dismissing, naming, appointing, punishing, impressing, deciding, prohibiting, allowing, and classifying. This research also has the pragmatic equivalent of subtitling of speech acts in Aladdin movie that consist of data coherence and data implicature.
\end{abstract}

Keywords-declarative speech acts, pragmatics equivalence, Aladdin movie 2019.

\section{INTRODUCTION}

Translation is defined in many ways according to different writers. Translation is translating the meaning of a text into another language by the way the author intended Sunanto, Dewi \& Nyandra (2016). Panou (2013) defines translation as transferring the idea or information from the source language (SL) to the target language (TL). In translating ideas, equivalence is important to make the translation sounds natural because translation is regarded as communication within text. Others underline the meaning of translation equivalence because when translators translate a set of word or sentences (Barker, 1992), it is important to transfer whether or not the language can be accepted.

One of difficulties in translation is the distinction for equivalence between source language and target language. The term equivalence is synonymous to concept that equivalence is the goal or product of the translation process (Widiyanto, 2017). Because translation is a process of finding equivalence, the goal is achieving the most natural equivalence between SL and TL. This equivalence can be obtained based on theories about translation, such as methods, procedures, or techniques. There are many strategies to solve the problems of equivalence of a translation (Nasifah, Hartono \& Yuliasri, 2018). The strategies include 1) the delivery of messages from the source language into the recipient's language by harmonizing vocabulary and grammatical aspects, (2) prioritizing the content equivalence rather than form, (3) choosing the most reasonable equivalence in the recipient's language while considering the closeness to the meaning contained in the source language, (4) prioritizing meaning rather than style, even though language style is also important, (5) and prioritizing the interests of the translation reader

The commonest problem with translation is that translators are usually translating SL to TL unnaturally (Panou, 2013). Dzikirullah (2009) also affirmed that translators have difficulties in translating because of the different culture of SL and TL. For example, in the translation script of a movie, some translation has equivalence, but some are not (Herlambang, 2018). In another study, it was found that in translating novels, most of the translation are equivalent but some are not equivalent (Septiarini, 2017). It is because translators were still influenced by their culture in translating. That is why some translations of the language in novels and movies are not fully natural.

Previous studies have used various strategies to improve equivalence of translation. Yet, little research about translation equivalent has been done to investigate pragmatic equivalence especially in declarative utterance in a movie. This study investigates the types of declarative utterance in the movie of Aladdin 2019 and examines pragmatic equivalence in the movie. Hence, the equivalence of translation is regarded as important for impacting on natural language. Since there are many types of declarative texts in a movie and the problems in equivalence, this study raises 2 questions, i.e.: (1) What are the variations of the language forms of declarative utterances in Aladdin movie 2019 and its subtitling? And (2) How is the equivalence of the speaker' intentions of declarative utterances in the Aladdin movie 2019 and their subtitling?

\section{THEORETICAL FRAMEWORK}

\section{A. Translation}

There are many considerations in creating a good translation. It may relate to accuracy, clarity and naturalness of language from the idea and meaning in SL to those in TL. This definition is simplified from scholar's statement such as Barker in his book A Textbook of Translation (Searle, 1969). Another scholar also added that translation consists of efforts to produce target text (TT) to the closest natural equivalent of source text 
(ST) message (Newmark, 1988). The first thing to consider in translation is meaning and the second is style. The definition shows four important things in the main issues of translation, namely: reasonable, faithful, same meaning and style.

\section{B. Speech acts}

Speech act theory and the conception of implicatures can be used is analyzing the equivalence of translation utterance. Usually, Speech act is arisen in communicating with the interlocutors which has a purpose. The goal of speech act can be in the form of giving information, asking questions, exchanging ideas, and so on. Speech act is "the minimal unit of communication" Septiani (2017). Speech act is divided into 5 types namely: representative, commissive, directive, expressive and declaration. Each type has its own definition. One of the definitions of speech act theory, i.e. declaration, is stated in the next theoretical framework.

\section{Declarative speech acts}

Declarative speech act is a speech act that contains information intended to create a new idea as a result of spoken utterances. In this type, the speakers want to change a thing through their speech. The declarative speech act can be classified into eleven types namely: convincing, surrender, dismissing, naming, appointing, punishing, impressing, deciding, prohibiting, allowing and classifying (Septiani, 2017)

- Convincing: In general, convincing means "capable of causing someone to believe that something is true or real. Searle (1969) mentioned one example of convincing utterance "I would like you to go now", which can be interpreted that the speaker convinces the listener to leave right now.

- Surrendering: In general, surrender can be interpreted as stop resisting or fighting to an enemy or opponent and submit to their authority.

- Dismissing: In general dismissing can be interpreted as remove from employment or office, typically on the grounds of satisfactory. Searle (1969) gives an example in the act of dismissing such as "You're fired." It can be interpreted that the speaker declares that the other person is being fired or dismiss from a job.

- Naming: In general, naming means capable of causing someone to believe something is true or real about someone else. An example of naming utterance is "Sally is a block of ice", which means someone is dubbing the person who has a cold or ignorant attitude (Searle, 1969).

- Appointing: Generally, appointing means assigning a job or role to someone.

- Punishing: Generally, punishing means inflicting a penalty or sanction on someone as retribution for an offence.

- Impressing: Generally, it means that making someone feel admiration and respect." (Searle, 1969) gives a general example of the declarative impression impressing "do you need my help, Cyntia?" It means that someone who offer help can impress someone.

- Deciding: in general, deciding means serving to resolve or settle something. Searle (1969) gives an example of "I now pronounce you man and wife." This sentence is usually pronounced by the priest in a marriage.

- Prohibiting: Searle (1969) gives one example sentence which is "I order you to stay away from my wife" this sentence means a husband warns someone to stay away from his wife.

- Allowing: In general, allowing means let someone to do something.

- Classifying: Searle (1969) gives an example of a classifying sentence that is "You have become aristocrat." This kind of sentence means classifying someone who has a high standard of living.

\section{Pragmatic Equivalence}

Equivalence in translation means there is equality between SL and TL. In translation it is supposed to find the equivalence in the target text. The meaning in TL should be almost the same as that in the SL (Barker, 1992). It means that the translators are responsible to translate the unit of text that can be understood to participants in TL. In making sense of translation, coherence and implicature are important aspects and they are difficult in cross-cultural communication area.

- Coherence: has a link between the meaning of one sentence with another sentence so that the whole text has a unified meaning. In coherence there is relation with the surface text. It is also connected to lexical and grammatical dependencies. Also when a text has coherencies, it means that the meaning can be perceived clearly by language user.

- Implicature: Implicature is not what is clearly said but what is implied. When a translator wants to translate, it is important to transfer the implied meaning in order to get the source text message [4]. Grice also mentioned that translator job is to recreate the message so that the culture in SL can be understood clearly in the TL.

\section{E. Aladdin Movie 2019}

Aladdin is a 2019 American musical fantasy film directed by Guy Ritchie, who wrote the screenplay along with John August. Produced by Walt Disney Pictures, this film is an adaptation of the 1992 Disney animated film with the same title written based on Aladdin's folklore, from a collection of epic stories titled One Thousand and One Nights. The film stars are Will Smith, Mena Massoud, Naomi Scott, Marwan Kenzari, Navid Negahban, Nasim Pedrad, and Billy Magnussen.

Aladdin movie 2019 tells about a poor young man named Aladdin who has a magic lamp. The lamp has the power to grant three requests from its master. However, it was not only Aladdin who wanted the lamp, Jafar, the sultan's advisor, also wanted to get the lamp for granting his wishes. Jafar has a wish 
to be the powerful man in the universe. However, because of his greedy wishes he was cursed by his own wish.

\section{Methodology}

This study is a qualitative research with descriptive approach. The object of the study was pragmatic equivalence of declarative utterances in the movie. Data were taken from primary and secondary sources. The primary data were obtained from the script in the movie. The secondary data were also taken from the movie script to support the data analysis. Data were collected using the following steps: watching the movie and then sorting the text from the movie that is related to pragmatic equivalence. The data were analyzed based on the theory of pragmatics by Searle (1969) and Barker (1992)

\section{FINDINGS AND DISCUSSION}

\section{A. Declarative speech act}

There are 61 declarative utterances found in the movie. The 61 declarative utterances could be classified into eleven types according to Searle's taxonomy, i.e.: convincing, surrendering, dismissing, naming, appointing, excommunicating, punishing, impressing, deciding, prohibiting, allowing, and classifying. The research then found that some data were pragmatically equivalent to the source text translation, but some were not, as shown in Table 1.

TABLE I. Classification of Pragmatic Equivalence in Alladin MOVIE

\begin{tabular}{|c|c|c|c|}
\hline \multirow{2}{*}{ No. } & \multicolumn{3}{|c|}{ Declarative Speech Acts } \\
\cline { 2 - 4 } & $\begin{array}{c}\text { Types of } \\
\text { Declarative } \\
\text { speech acts }\end{array}$ & $\begin{array}{c}\text { Equivalent } \\
\text { Translation }\end{array}$ & $\begin{array}{c}\text { Non } \\
\text { Equivalent } \\
\text { Translation }\end{array}$ \\
\hline 1 & Convincing & 7 & 1 \\
\hline 2 & Surrender & 1 & - \\
\hline 3 & Dismissing & 1 & 1 \\
\hline 4 & Naming & 5 & 1 \\
\hline 5 & Appointing & 4 & 3 \\
\hline 6 & Punnishing & 1 & 2 \\
\hline 7 & Impressing & 10 & 2 \\
\hline 8 & Deciding & 9 & 3 \\
\hline 9 & Prohibitting & 4 & - \\
\hline 10 & Allowing & 3 & 1 \\
\hline 11 & Classifying & 2 & - \\
\hline & Total & 47 & 14 \\
\hline
\end{tabular}

\section{B. Pragmatic Equivalence}

The researchers found out 47 data categorized as pragmatically equivalent. It means that most of declarative utterances in Aladdin movie 2019 had implied meaning. Some were in the forms of direct utterances that did not flout maxim. The table above shows 11 types of declarative utterances used in the movie. The most dominant was impressive utterance. There were 10 data that were categorized as impressing utterance. The following are the examples of equivalent translations:

1) Convincing : causing someone to believe that something is true or real. The following is one example of convincing in Aladdin movie.

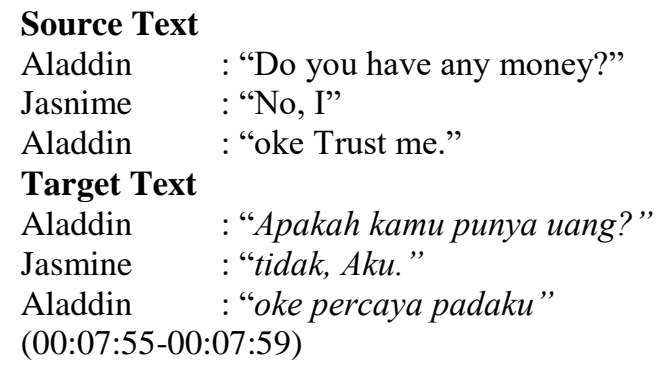

The conversation happens when a salesperson asks for Jasmine's bracelet to make up for the bread she gives to children. At that time Aladdin tells her to bring his bracelet to the seller. But Aladdin is a cunning magician. Instantly, Aladdin can get Jasmine's bracelet back on his hands. It is the reason why Aladdin asks Jasmine to believe in him. It also has coherence when Aladdin request Jasmine to believe in him, she just gave her bracelet to Aladdin. It means that Aladdin's words by saying "ok, Trust me" was perceived well by Jasmine

2) Surrendering: the action for stopping in a situation. An example from Alladin movie is in the below
Source text
Aladdin : "Nothing seems to impress her."
Target text
Aladdin

$$
\text { : "tidak ada sepertinya yang membuat dia }
$$ terkesan."

(01:10: 22- 01:10:24)

This expression was stated by Aladdin when he almost gives up because he is confused how to make the princess impressed with him.

3) Dismissing: ordering someone to leave to another place. Here is the example of dismissing in Aladdin movie.

Source Text

Horse rider : "Street Rat! get out of the way!"

Target Text

Penunggang kuda: "Tikus jalanan! minggir dari jalanan!" (00:18:06- 00:18:08)

This conversation happened when a horse rider in a fierce tone tells Aladdin to step aside from the road because Aladdin is blocking his way. This shows that the rider wants Aladdin to dismiss from the street. 
4) Naming: giving a name to someone. Here is the example of naming in Aladdin movie.

\section{Source Text}

Horse Rider : "Street Rat! Get out of the way!

Aladdin : "What do you think who you are street rat."

\section{Target Text}

Penunggang kuda : "Tikus jalanan! Minggir dari jalanan."

Aladdin : "Siapa yang kau panggil tikus

$$
\text { jalanan?" }
$$

(00: 18: 06- 00:18:12)

This conversation occurred when Aladdin accidentally blocked the path of the horseman. without knowing Aladdin's background the rider just called Aladdin a "Street Rat".

5) Appointing: roling someone. The example of appointing in Aladdin movie is below:

\section{Source text}

Aladdin : "I don't think you know who I am."

Jaffar : "Oh no no, I know who you are Aladdin."

Target text

Aladdin : "Aku fikir kamu tidak tau siapa aku."

Jaffar : "Oh tidak tidak aku tahu siapa kamu."

(01:23:20- 01:23:24)

This conversation was taken place in Jafar's room. Jafar wanted Aladdin to admit that prince Ali is Aladdin (a street rat). Jafar directly appoint prince Ali because Jafar already know Prince Ali's background. He was together with Aladdin when they were outside cave.

6) Punishing: giving penalty or sanction to someone who is guilty. Here is the example of punishing utterance in the movie

\section{Source text}

Aladdin : "Your majesty, he wants your throne."

Sultan : "You are my trusted advisor. Hakim, put him in dungeon."

\section{Target text}

$\begin{array}{ll}\text { Aladdin } & \text { : "Yang mulia, dia inginkan tahtamu." } \\ \text { Sultan } & \text { : "Kau adalah penasehat yang ku percaya. } \\ & \text { Hakim taruh dia dalam penjara bawah } \\ & \text { tanah." }\end{array}$

$(01: 29: 42-01: 29: 53)$

This conversation happened when the sultan was under Jafar's hypnosys who used his wand. But Prince Ali broke the stick so that Jafar's hypnosys immediately disappeared. Finally, the sultan realized that Jafar who had been trusted by him had betrayed him and even wanted his throne.

7) Impressing: making someone admiring someone else. One example on impressing utterance is as follows:

\section{Source text}

Ginnie : "I said I'm the most powerful in the universe."

\section{Target text}

Ginnie

$$
\begin{aligned}
& \text { : "Aku bilang aku paling kuat di alam } \\
& \text { semesta." }
\end{aligned}
$$

(00:48:10- 00:48:20)

In the example above, the situation occurs when Genie tells Aladdin that he is the most powerful creature in the universde to make him impressed. He said that there was no other creature that was stronger than him, so he could grant something that Aladdin asked for but he could not make someone love someone and could not kill someone.

8) Deciding : having resolution after making consideration. Here is one deciding utterance:

\section{Source text}

Aladdin : "I will use my $3^{\text {rd }}$ wish to set you free."

Target text

Aladdin : : "Aku akan menggunakan harapan ketigaku untuk menyelamatkanmu."

(00:51:09-00:51:14)

The sentence above is assumed by Aladdin because Aladdin previously asked Ginnie about what Ginnie dreamed of. Ginnie answered that he wanted to be free and live like an ordinary human. Aladdin said he would make his $3^{\text {rd }}$ wish to free Ginnie.

9) Prohibiting: forbiding someone because of law or rules or authority. Below is the example of prohibiting utterance in Aladdin movie.

Source text

Sultan: "Don't touch her"

Target text

Sultan: "Jangan sentuh dia."

(01:37:19-01:37:22)

Sultan uttered that kind of utterence when he saw his daughter who would be taken somewhere by the guards. At that time Jafar held a magic lamp and asked Jinny to make him a Sultan. Jinny granted Jafar's request but Jasmine did not accept what Jafar had done because Jafar was immediately captured by the kingdom.

10) Allowing: admitting time and opportunity to someone. Here is the example of allowing according to Alladin movie.

\section{Source text}

Sultan : "You may leave now."

Target text

Sultan : : "Kamu boleh pergi sekarang."

Sultan alleged that when Jasmine entered the Sultan's office and talked with Jafar and the sultan himself. When 
Jasmine's proposal was rejected, she looked very sad. Because Sultan could not bear to see Jasmine crying, the sultan asked Jasmin to leave the room.

11) Classifying: arranging group of people or things in class according to qualities, experiences, and also characteristics. Below is the classifying utterance that was uttered by character in Aladdin movie

\section{Source text}

Aladdin : "Well, only someone from the palace could afford a bracelet like that."

\section{Target text}

Aladdin: "Hanya sesorang dari istana yang mampu beli gelang seperti itu."

The utterance is spoken by Aladdin to Jasmine while they met in the market when jasmine gave bread to the children. Because he did not have the money to buy it the merchant demanded jasmine to give the jewelry. Immediately Aladdin came and Aladdin gave the bracelet to the seller, but Aladdin then took it back and ran away with jasmine. When they have time to talk Aladdin asked jasmine how she had got a nice bracelet. Jasmin then confessed that he was a palace maid. After that Aladdin said that it is impossible for a servant to have a bracelet like that.

\section{B. Pragmatic Non-equivalence}

In this study, source text and target text has no equivalency if an implicated utterance translated to implicated utterance in target text with different meaning. The study shows that there are 14 data that are categorized as non-equivalent. Most of them are not equivalent because the expressions in ST and in TT have different meanings. For example:

\section{Source text}

Sultan

: "You will have a chance to speak, you can join us Prince Ali."

Prince Ali

$$
\text { : "Of course we will join you." }
$$

\section{Target text}

Sultan

Prince Ali

: "Kamu tidak akan mendapatkan
kesempatan bicara lagi, kami harap kau bisa
gabung dengan kami malam ini."
:"Baiklah kita akan mengikutimu"

\section{Situation}

This conversation occurred when Prince Ali faced the Sultan. It seems that Prince Ali doesn't know how to be an authoritative prince. When Prince Ali revealed all his wealth and would give a gift to the Sultan of Agrabah. but Prince Ali looks excessive.

The above example shows the use of implicated utterance in source text, which is declarative utterance in types of allowing someone to join party. We can see the difference between source text and target text. In source text it is said you will have a chance to speak. However, the target expression has different or contradictory meaning to source text that is "kamu tidak akan mendapatkan kesempatan bicara lagi" (you'll have no chance to speak). This kind of translation will give different meaning to the target audience. That is why good equivalency is important to be delivered.

\section{CONCLUSIONS}

Considering declarative utterances in Aladdin movie 2019 from English into Indonesian, most translations have pragmatic equivalence. There are 61 data identified as declarative utterances, and can be classified into 11 categories. The types of the declarative utterences include convincing, surrendering, dismissing, naming, appointing, punishing, impressing, deciding, prohibiting, allowing and classifying. Out of the total of 61 data, 47 data of translation were considered equivalent and only 17 data as non equivalent. The non-equivalent data occurred as the meaning of TT was different from the one in ST.

As has been discussed above, the criteria of equivalence depend on the context and the goal of translation itself. We sometimes find the differences between the source language and the target language due to the different cultures existing in both langauges. Therefore, it's a translator duty to find an appropriate way to make the translation equivalence, because one of the goals in translation is finding equivalence. Here, we think that the most fundamental one is to keep the meaning equivalent between source and target text. The associative meaning should be valued during college English teaching. Teachers should have the awareness that communication is the main function of learning English. As one of the basic skills of learning language, translation should contribute in understanding the linguistic and cultural differences between source language and target language

There are number of limitations of this current research, some may have affected on the quality of analysis. One limitation has relation in finding pragmatics equivalence. The equivalence we found is still according to the research opinion so that we think it needs to be expanded. It may need more respondents to evaluate whether the pragmatics meaning is according to researcher's opinion or not. Therefore it needs further exploration. Other limitations are regarding on research approach. For instance, the analysis and the evidence may be subjective according to the researchers' own culture. It will be better if there are insights from people with different cultural backgrounds. Finally, for future research it will be good if the researcher provide more detailed analysis regarding pragmatic equivalence in translation.

\section{REFERENCES}

Barker M. 1992. In Other Words: a course Book on Translation. Sage Publication: London

Cuellar, S. B. n.d. Equivalence Revisited: A Key Concept in Modern Translation Theory. Article. Universidad Nacional de Colombia 
Dzikirullah, B. 2009. Word, Above Word, and Gramatical Equivalence in The Subtitle of Troy. Under-Graduate Thesis, Universitas Negri Semarang

Herlambang, M. 2018. A Study of Translation Equivalence and Acceptability on The subtitle of Intel Advertisements. Sanata Dharma University

Nasifah, N., Hartono, R., \& Yuliasri, I. 2018. Translation Methods and Degree of Equivalence English-Indonesian Translation of Leo Tolstoys God See

Newmark, P. 1988. A textbook of Translation. Pergamon Press: Oxford Nida, E. A., \& Taber, B. 1982. The Theory and Practice of Translation. Leiden: E. J. Brill.

Panou, D. 2013. Equivalence In Translation: A Critical Evaluation. Theory and Practice In language Studies, 3(1), pp 1-6.
Searle, J.R. 1969. Speech Acts: an Essay in the Philosophy of Language. Cambridge UniversityPress: Cambridge.

Septiani. 2017. Equivalence Strategy Used in Translating The Hunger Games Novel into Indonesian. Universitas Muhammadiyah Surakarta.

Susanto, P., Dewi, P. \& Nyandra, M. 2016. The Serach of Equivalence in Translating Seven Character Traits of Dyana Putri. Padang: Padang State University

Widiyanto. 2017. Translation Strategies of Non-equivalence at Word Level in Morris and Hartog Van Banda Comic Lucky Luke Ghost Hunt. Faculty of Hummanities Dian Nuswantoro University Semarang 